\title{
The Effectiveness of Electronically Personalized System of Instruction by Using Hypermedia in Learning the Skill of Overhand Passing in Volleyball "Dr/ Naglaa Abdel Moneim El Barbary
}

\section{Abstract:}

The research aimed to develop a proposed educational program of Personalized System of Instruction (Keller Plan), using hypermedia, and identify its effect on the performance level of overhand passing skill in volleyball among the first-year female students in the Faculty of Physical Education, Port Said University. The researcher used the experimental method applying on a sample of 40 first-year female students at Faculty of Physical Education, Port Said University. The sample was divided into two groups, experimental and control group. Each group consisted of 20 female students. The research tools included physical and skill tests, high intelligence test, and the proposed educational program of Personalized System of Instruction (Keller Plan) by using hypermedia.
The most significant findings include:

1. Electronically

Personalized System of Instruction by using hypermedia positively impact the performance level of overhand passing in volleyball among the experimental group members (low level, high level).

2. The effectiveness of electronically Personalized System of Instruction by using hypermedia is greater than instruction approach in the performance level of overhand passing in volleyball.

The most significant recommendations include:

1. Personalized System of Instruction (Keller Plan) by using hypermedia should be used in learning and mastering skill of overhand passing in volleyball for female students of Faculty of Physical Education in Port Said.

Assistant Professor, Department of Team Sports Theories \& Applications, Faculty of Physical Education, Port Said University 
2. Initial evaluation should be conducted to classify the female students from the beginning to equal performance groups.

\section{Introduction and Problem:}

Personalized System of Instruction is a method to manage the instruction process so that learners could merge in learning tasks corresponding with their needs and levels. It may be a method providing them with opportunity to study the scientific material according to their abilities and the speed of their learning; under the supervision of a teacher who assisted them in solving the problems, they face during their studies to achieve their educational goals.

Keller Plan is characterized by performance proficiency in quick learning in line with the learner's abilities, potentials, level (low, high), and desires allowing him to adjust his achievement during the learning of curriculum content as long as the learning proficiency is a prerequisite for Keller Plan. It is natural that amount of time that each learner needs to achieve the required level, and the proficiency of learning content is different due to the different self-speed of each learner.

As one of Personalized System of Instruction methods, Keller Plan is based on learner's studying of educational material according to his own abilities and speed. Thus, the basic principle upon which this strategy in learning based is that the learner absorbs and masters every concepts and skills of educational module before moving on to the followed module. It, therefore, requires each learner to be a contributed and an effective member in the educational process instead of being only negative receiver of the information passed to him by the teacher. Learner must be an involved and effective element in all activities, to master the specified educational objectives.

Hypermedia is one of the most advanced educational techniques. It includes the integration of various forms of means through which can be controlled by computer. The basic feature of this technology is that it has a high degree of learner's interaction with many sources of information. Wafika Mustafa (2001) and Michelle (2010) indicated that 
hypermedia is an educational strategy used in providing and transferring information in non-linear way. [31, 35] It is also used to take advantage of learner's sensory entries "visual, auditory", and to provide interaction between the learner and a set of educational multi-media, on which information is stored in the form of (written texts, moved and fixed video clips, cartoons, films and consistent colors, sounds and music) recordings. In addition, it provides quickly and easily control in this information to allow the learner configure logical links that facilitate the transition and free movement in non-linear forms between the parts of information stored and fragmented into small pieces with the help of computer to efficiently and effectively achieve the educational goals of the educational program.

Ellen Wadih Farag (1990) and Ali Mustafa Taha (1999) agreed that passing skill is directing the ball with hands and changing its direction without stability on the hands. $[5,18]$ It is one of the most important and widely used skills in volleyball. A team's success depends on the players' ability to control correctly and legally the direction of the ball in all directions. It is also the most important skill for defense and attack plans used by the team in playing.

Through the researcher's experience in teaching volleyball curriculum for the first-year female students at Faculty of Physical Education, Port Said University, she noted the low performance level of female students in overhand passing skill in volleyball. This turned out by the results of the applied tests in the college for the first semester of the academic year 2013/2014. Thirty-two percent (32\%) of the first-year female students had a weak level. This percentage is large. The researcher attributed the reason to the use of instruction approach (traditional method) in teaching, which depends on a single source of knowledge. It is a verbal explanation followed by presenting the model without any actual participation from the female student in the educational situation. In addition, some female learners may not follow the explanation or find that it is difficult to understand what is required from them. This 
method also does not take into account individual differences among the female learners. Moreover, some practical lectures in the college are still lack the most basic means of education because the female teacher based on the traditional method in explaining the skill; that is, she depends on orderlearning method unsupported with any other simple mean, such as moving or still pictures that enhance learning.

Thus, the idea of research has emerged as a scientific attempt to identify the effectiveness of Personalized System of Instruction (Keller Plan) by using hypermedia in learning overhand passing skill in volleyball for the first-year female students at Faculty of Physical Education, Port Said University. To the researcher's knowledge, no scientific study addressed the use of Personalized System of Instruction (Keller Plan) by using hypermedia in learning handover-passing skill in volleyball, which makes it a modern research.

\section{Objective:}

This research aims to develop a proposed educational program of Personalized
System of Instruction (Keller Plan) by using hypermedia, and to identify its effect on the performance level of overhand passing skill in volleyball for the first-year female students at Faculty of Physical Education, Port Said University.

\section{Hypotheses:}

1. There would be statistically significant differences between both preand post-tests of the experimental group (low level, high level) in the performance level of overhand passing skill in volleyball in favor of posttest.

2. There would be statistically significant differences between both preand post-tests of the control group (low level, high level) in the performance level of overhand passing skill in volleyball in favor of post-test. 3. There would be statistically significant differences between both posttests of both the experimental and control group (low level, high level) in the performance level of overhand passing skill in volleyball in favor of the experimental group.

Procedures:

Methodology: 
The researcher adopted the experimental method using pre- and post-tests of both groups. The experimental group used Personalized System of Instruction (Keller Plan) by hypermedia, and the other, the control group, used the traditional method (instruction approach) in the style of learning.

Sample:

The

researcher

deliberately selected the research sample, consisting of 50 first-year female students at Faculty of Physical Education, Port Said University in the first semester of the academic year 2014/2015. Ten (10) female

students were excluded for the

Table (1)

Distribution of Female Students According to Level of Skill Performance in Experimental and Control Groups

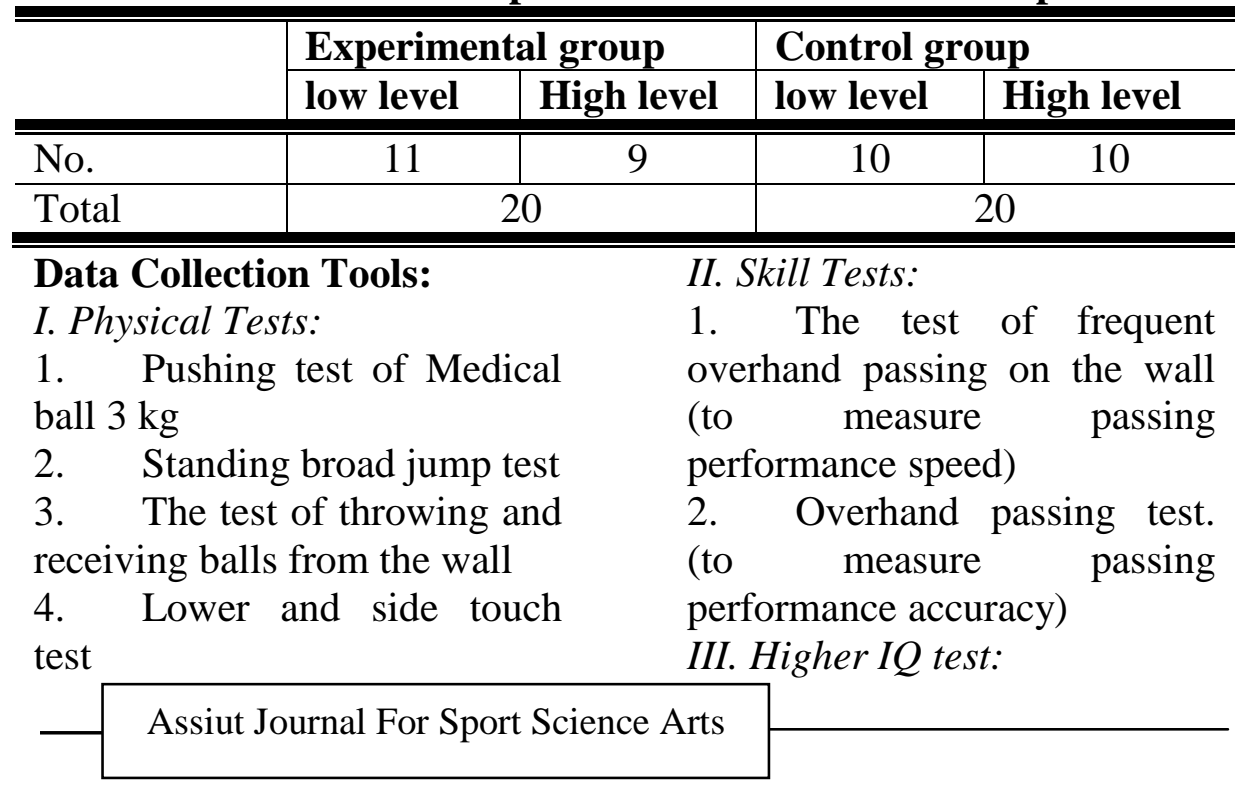

survey. Thus, the core sample became 40 female students divided into two equal groups; one is an experimental group and the other is a control group. Each consisted of 20 female students.

Division of Experimental and Control Groups:

The researcher organized, in descending order, the results of the female students in the performance level of overhand passing skill in volleyball. Then the female students were divided into two levels in the both experimental and control groups (low level, high level). Table (1) illustrates this. 
Prepared by Mohamed Khairy (1987) [3]

The Educational Program using Personalized System of Instruction (Keller Plan) by hypermedia:

I. The program overall objective:

The program aims to learn and master overhand passing skill in volleyball for the first-year female students at Faculty of Physical Education, Port Said University.

II. The foundations of developing the educational program:

1. To provide information contained in the educational program in an integrated framework and uses all the senses of the female learner,

2. To create an exciting environment for teaching and learning by the female teacher to lead the learner to master what she learns. This increases the effectiveness of education in terms of understanding, analysis, and evaluation,

3. To gradate the program from easy to difficult, as appropriate for the level of each female student,

4. To present all drawings, photos, and videos by computer and the written text,
5. To provide an opportunity for all female learners to practice and work at the same time, and to make progress in their teaching to achieve the goal in sequential manner,

6. To take into account the shape and the size of sequence drawings, photos, videos, and written text in proportion to the size of the screen,

7. The program identifies the content of the abilities and capabilities of the female learners, including taking into account individual differences and their motivation to learn,

8. The logical sequence of the program contents is consistent with the objectives and with the sample properties, 9. To observe diversity, inclusiveness, and simplicity of the program to satisfy the motor desires of the female student,

III. Software Content

Determination:

The content selection is of the most important steps to build the software process. This importance is represented in selecting facts and information associated with overhand passing skill in volleyball. In addition to selecting video clips, illustrations, and other 
educational materials that were chosen, and organizing them in a certain educational aspect, and determining how to handle them to help achieve the goals of the software.

IV. Software Production Stages:

Through access to many specialized scientific references, such as Abdul Hamid Sharaf (2001), Mohamed Saad Zaghloul et al. (2001), Wafika Mustafa (2001), Abdul Hafiz Mohamed (2012), and scientific studies that dealt with hypermedia method, in particular, for designing the educational program in the light of the specific objectives. [14, 27, 31, 13]

\section{Writing Scenario Stage:}

The program's scenario is set up in light of the general objectives to be accessible and the scientific material of the skill under discussion. The following steps are adopted:

1. Preparation of Program's Scenario in Its Initial Form:

The program's scenario has been prepared in its initial image and displayed on specialists in the field of volleyball and teaching methods, Annex (4). This aims to view the specialists' opinions in the general objective of the program, program foundations, program content, scientific accuracy, and presentation style within the software, program requirements, and program applicable. The experts indicated that some adjustments are necessary so that the program could be applicable.

2. Preparation of Program's Scenario in Its Final Form:

After making the necessary adjustments referred to by specialists, the program's scenario has been presented after making these amendments again on these specialists. Through the review of the specialists' opinions by researcher, it became clear that they approved the final form of the scenario with a percentage of $100 \%$. Thus, the software has become in its final form ready for implementation.

3. Time Frame for Using the Software:

- The total number of weeks is 5 weeks, which is the period of applying the experiment,

- The allocated time to each lecture is 90 minutes, which is the time of applied 
lectures in the faculty. Fortyfive (45) minutes were extracted for the implementation of the proposed educational program, distributed as follows:

- Watching hypermedia software for 5 minutes,

- Physical preparation for 10 minutes,

- Educational and practical part for 30 minutes.

Pre-tests:

The pre tests of the variables under discussion were conducted for the both experimental and control groups (low level, high level) from 21/10/2014 to 23/10/2014. These tests are considered as conducting equality between the two groups of research. This was done after conducting scientific coefficients (validity, reliability) of physical, skill tests, and IQ test under discussion. Tables (2) and (3) illustrate this.

Table (2)

Significance of Differences between Experimental and Control Groups (Low Level) in Variables under Discussion

\begin{tabular}{l|l|l|l|l|l|l}
\hline \multirow{2}{*}{ Variables } & \multirow{2}{*}{$\begin{array}{c}\text { Measure } \\
\text { unit }\end{array}$} & \multicolumn{2}{c|}{$\begin{array}{c}\text { Experimental } \\
\text { group n 11 }\end{array}$} & \multicolumn{2}{c|}{$\begin{array}{c}\text { Control } \\
\text { group n 10 }\end{array}$} & \multirow{2}{*}{$\begin{array}{c}\text { "t" } \\
\text { value }\end{array}$} \\
\cline { 3 - 7 } & & $\mathbf{M}$ & $\mathbf{S}$ & $\mathbf{M}$ & $\mathbf{S}$ & \\
\hline \hline Age & Year & 18.25 & 0.54 & 18.36 & 0.51 & 0.45 \\
\hline Length & $\mathrm{cm}$ & 165.19 & 4.71 & 165.81 & 4.49 & 0.29 \\
\hline Weight & Kg & 67.00 & 5.19 & 67.70 & 4.72 & 0.31 \\
\hline IQ & Degree & 29.97 & 4.64 & 29.55 & 4.33 & 0.21 \\
\hline Arms muscle ability & Meter & 3.91 & 0.38 & 3.85 & 0.31 & 0.38 \\
\hline Legs muscle ability & Meter & 1.35 & 0.12 & 1.30 & 0.15 & 0.81 \\
\hline Compatibility & Degree & 12.55 & 2.46 & 12.27 & 2.38 & 0.25 \\
\hline Dynamic flexibility & Number & 18.11 & 3.02 & 17.69 & 3.11 & 0.31 \\
\hline $\begin{array}{l}\text { Speed performance of } \\
\text { forward overhand passing }\end{array}$ & Number & 4.19 & 1.77 & 4.00 & 1.69 & 0.11 \\
\hline $\begin{array}{l}\text { performance } \\
\text { accuracy of forward } \\
\text { overhand passing }\end{array}$ & Degree & 1.55 & 0.92 & 1.61 & 0.95 & 0.14 \\
\hline \hline
\end{tabular}

The value of tabular " $t$ " at the level of $0.05=2.093$

Table (2) indicates that there are no statistically significant differences at the level 0.05 between the experimental and control groups (low level) in age, height, weight, intelligence, and physical and skill variables under 
discussion. This indicates that are equal in these variables. the members of both groups

Table (3)

Significance of Differences between Experimental and Control

Groups (High Level) in Variables under Discussion

\begin{tabular}{l|l|l|l|l|l|l}
\hline \hline \multirow{2}{*}{ Variables } & Measure & \multicolumn{2}{|l|}{$\begin{array}{l}\text { Experimental } \\
\text { group } \\
\text { unit }\end{array}$} & $\begin{array}{l}\text { Control } \\
\text { group } \\
n=10\end{array}$ & \multirow{2}{*}{$\begin{array}{l}\text { " } \boldsymbol{t}^{\prime \prime} \\
\text { value }\end{array}$} \\
\cline { 3 - 7 } & $\mathbf{M}$ & $\mathbf{S}$ & $\mathbf{M}$ & $\mathbf{S}$ & \\
\hline \hline Age & Year & 18.40 & 0.56 & 18.35 & 0.53 & 0.19 \\
\hline Length & cm & 166.57 & 5.79 & 166.90 & 5.31 & 0.13 \\
\hline Weight & Kg & 68.00 & 5.13 & 67.35 & 4.96 & 0.27 \\
\hline IQ & Degree & 29.87 & 4.91 & 30.00 & 4.77 & 0.11 \\
\hline Arms muscle ability & Meter & 3.82 & 0.36 & 3.91 & 0.39 & 0.49 \\
\hline Legs muscle ability & Meter & 1.37 & 0.14 & 1.40 & 0.15 & 0.42 \\
\hline Compatibility & Degree & 12.61 & 2.41 & 12.87 & 2.69 & 0.21 \\
\hline $\begin{array}{l}\text { Dynamic } \\
\text { flexibility }\end{array}$ & Number & 18.23 & 3.26 & 18.45 & 3.12 & 0.14 \\
\hline $\begin{array}{l}\text { Speed performance } \\
\text { of forward } \\
\text { overhand passing }\end{array}$ & Number & 4.29 & 1.95 & 4.47 & 2.03 & 0.19 \\
\hline $\begin{array}{l}\text { performance } \\
\text { accuracy of forward } \\
\text { overhand passing }\end{array}$ & Degree & 1.75 & 1.03 & 1.81 & 1.11 & 0.12 \\
\hline \hline
\end{tabular}

The value of tabular " $t$ " at the level of $0.05=2.110$

Table (3) indicates that there are no statistically significant differences at the level 0.05 between the experimental and control groups (high level) in the variables under discussion. This indicates that the members of both groups are equal in these variables.

The Application of Educational Program by Using Electronically

Personalized System of Instruction:

The researcher applied the content of the educational program by using electronically Personalized System of Instruction on the experimental group, for (5) weeks consecutively, from $26 / 10 / 2014$ to $29 / 11 / 2014$. The traditional method was used with the control group. 
Post-tests:

The post-tests were conducted on the two groups of research (low level, high level) from $01 / 12 / 2014$ to $03 / 12 / 2014$ in the performance level of overhand passing skill in volleyball in the same order and conditions of the pre tests.

Presentation and Discussion of Findings:

I. Presentation of Findings:

\section{Table (4)}

Significance of Differences between Both Pre- and Post-Tests of Experimental Group (Low Level) in Skill Variables under Discussion $\mathbf{n}=11$

\begin{tabular}{|c|c|c|c|c|c|c|}
\hline \multirow{2}{*}{ Variables } & \multirow{2}{*}{$\begin{array}{l}\text { Measure } \\
\text { unit }\end{array}$} & \multicolumn{2}{|c|}{ Pre-test } & \multicolumn{2}{|c|}{ Post-test } & \multirow{2}{*}{$\begin{array}{l}" t " \\
\text { value }\end{array}$} \\
\hline & & $\mathbf{M}$ & $\mathbf{S}$ & $\mathbf{M}$ & $\mathbf{S}$ & \\
\hline $\begin{array}{lr}\text { Speed performance of } \\
\text { forward } \\
\text { passing }\end{array}$ & Number & 4.19 & 1.77 & 20.51 & 2.14 & $17.91 *$ \\
\hline $\begin{array}{ll}\text { performance } & \text { accuracy } \\
\text { of forward } & \text { overhand } \\
\text { passing } & \\
\end{array}$ & Degree & 1.55 & 0.92 & 15.29 & 1.18 & $28.64 *$ \\
\hline
\end{tabular}

The value of tabular " $t$ " at the level of $0.05=2.228$

* Significance at the level of 0.05

Table (4) indicates that there are statistically significant differences at the level of 0.05 between both pre- and post-

Table (5)

Significance of Differences between Pre- and Post-Tests of Control Group (Low Level) in Skill Variables under Discussion N = 10

\begin{tabular}{|c|c|c|c|c|c|c|}
\hline \multirow{2}{*}{ Variables } & \multirow{2}{*}{$\begin{array}{l}\text { Measure } \\
\text { unit }\end{array}$} & \multicolumn{2}{|c|}{ Pre-test } & \multicolumn{2}{|c|}{ Post-test } & \multirow{2}{*}{$\begin{array}{l}" t " \\
\text { value }\end{array}$} \\
\hline & & $\mathbf{M}$ & S & $\mathbf{M}$ & $\mathbf{S}$ & \\
\hline $\begin{array}{l}\text { Speed performance } \\
\text { of forward overhand } \\
\text { passing }\end{array}$ & Number & 4.00 & 1.69 & 17.85 & 2.26 & $14.85^{*}$ \\
\hline $\begin{array}{l}\text { performance } \\
\text { accuracy of forward } \\
\text { overhand passing }\end{array}$ & Degree & 1.61 & 0.95 & 13.17 & 1.11 & $22.97 *$ \\
\hline
\end{tabular}

The value of tabular " $t$ " at the level of $0.05=2.262$

* Significance at the level of 0.05 Assiut Journal For Sport Science Arts 
Table (5) indicates that there are statistically significant differences at the level of 0.05 between both pre- and posttests of the control group (low

\section{Table (6)}

Significance of Differences between Post-Tests of Experimental and Control Groups (Low Level) in Skill Variables under

\section{Discussion}

\begin{tabular}{l|l|c|c|c|c|c}
\hline \hline \multirow{2}{*}{ Variables } & \multirow{2}{*}{$\begin{array}{l}\text { Measure } \\
\text { unit }\end{array}$} & \multicolumn{2}{|c|}{$\begin{array}{c}\text { Experimental } \\
\text { group } n=11\end{array}$} & \multicolumn{2}{|c|}{$\begin{array}{c}\text { Control } \\
\text { group } n= \\
\mathbf{1 0}\end{array}$} & \multirow{2}{*}{$\begin{array}{c}\text { " } \boldsymbol{t}^{\prime \prime} \\
\text { value }\end{array}$} \\
\cline { 3 - 6 } & $\mathbf{M}$ & $\mathbf{S}$ & $\mathbf{M}$ & $\mathbf{S}$ & \\
\hline \hline $\begin{array}{l}\text { Speed performance of } \\
\text { forward overhand passing }\end{array}$ & Number & 20.51 & 2.14 & 17.85 & 2.26 & $2.63^{*}$ \\
\hline $\begin{array}{l}\text { performance accuracy of } \\
\text { forward overhand passing }\end{array}$ & Degree & 15.29 & 1.18 & 13.17 & 1.11 & $4.02^{*}$ \\
\hline \hline
\end{tabular}
of overhand passing skill in volleyball in favor of the posttest. level) in the performance level
* Significance at the level of 0.05

Table (6) indicates that there are statistically significant differences at the level of 0.05 between post-tests of both the experimental and control 
the experimental group (high level) in the performance level volleyball in favor of the posttest. of overhand passing skill in

\section{Table (8)}

Significance of Differences between Pre- and Post-Tests of Control Group (High Level) in Skill Variables under Discussion $\mathbf{n}=\mathbf{1 0}$

\begin{tabular}{l|l|c|c|c|c|c}
\hline \hline \multirow{2}{*}{ Variables } & \multirow{2}{*}{$\begin{array}{l}\text { Measurement } \\
\text { unit }\end{array}$} & \multicolumn{2}{|c|}{ Pre test } & \multicolumn{2}{|c|}{ Post test } & \multirow{2}{*}{$\begin{array}{c}\text { " }{ }^{\prime \prime} \\
\text { value }\end{array}$} \\
\cline { 3 - 6 } & $\mathbf{M}$ & $\mathbf{S}$ & $\mathbf{M}$ & $\mathbf{S}$ & \\
\hline $\begin{array}{l}\text { Speed performance } \\
\text { of forward overhand } \\
\text { passing }\end{array}$ & Number & 4.47 & 2.03 & 21.19 & 2.21 & $17.41^{*}$ \\
$\begin{array}{l}\text { Performance } \\
\text { accuracy of forward } \\
\text { overhand passing }\end{array}$ & Degree & 1.81 & 1.11 & 14.37 & 1.13 & $23.28^{*}$ \\
\hline \hline
\end{tabular}

The value of tabular " $\mathrm{t}$ " at the level of $0.05=2.262$

* Significance at the level of 0.05

Table (8) indicates that there are statistically significant differences at the level of 0.05 between pre- and post-tests of the control group (high level)

in the performance level of overhand passing skill in volleyball in favor of the posttest.

Table (9)

Significance of Differences between Both Post Tests of Experimental and Control Groups (High Level) in Skill Variables under Discussion

\begin{tabular}{|c|c|c|c|c|c|c|}
\hline \multirow[t]{2}{*}{ Variables } & \multirow{2}{*}{$\begin{array}{c}\text { Measure } \\
\text { unit }\end{array}$} & \multicolumn{2}{|c|}{$\begin{array}{c}\text { Experimental } \\
\operatorname{group} n=9\end{array}$} & \multicolumn{2}{|c|}{$\begin{array}{c}\text { Control } \\
\text { group } n=10\end{array}$} & \multirow{2}{*}{$\begin{array}{c}\text { "t } t " \\
\text { value }\end{array}$} \\
\hline & & $\mathbf{M}$ & $\mathbf{S}$ & $\mathbf{M}$ & $\mathbf{S}$ & \\
\hline $\begin{array}{l}\text { Speed performance of } \\
\text { forward overhand passing }\end{array}$ & Number & 24.56 & 2.17 & 21.19 & 2.21 & $3.17 *$ \\
\hline $\begin{array}{l}\text { Performance accuracy of } \\
\text { forward overhand passing }\end{array}$ & Degree & 16.23 & 1.24 & 14.37 & 1.13 & $4.67 *$ \\
\hline
\end{tabular}

The value of tubular "t" at the level $0.05=2.110$

* Significance at the level of 0.05

Table (9) indicates that there are statistically of experimental and control significant differences at the groups (high level) in the 
performance level of overhand passing skill in volleyball in favor of the experimental group.

\section{Results Discussion:}

\section{A. First Hypothesis}

\section{Results Discussion:}

The results of table (4) indicated that there are statistically significant differences at the level of 0.05 between pre and post-tests of the experimental group (low level) in the performance level of overhand passing skill in volleyball in favor of the posttest.

The results of table (7) also indicated that there are statistically significant differences at the level of 0.05 between pre- and post-tests of the experimental group (high level) in the performance level of overhand passing skill in volleyball in favor of the posttest.

The researcher attributed this improvement in the performance level of overhand passing skill in volleyball of the experimental group (low level, high level) to the effectiveness of Electronically Personalized System of Instruction Keller Plan by using hypermedia through the computer (such as video clips, still images, written texts). This is conducted by watching the ideal models in the performance of overhand passing skill in volleyball and reading the written text of the educational steps and the stages of the technical performance of the skill. All these effectively contributed to the female student's learning to the skill under discussion and absorbed it according to her own abilities. This contributes to take into account the individual differences in motor learning. This is consistent with that indicated by Najar Lawrance (2005) that the degree of learner's dazzle of non-traditional learning methods works to attract his attention towards the learning topic, which increases his motor and cognitive achievement.

This result is also consistent with the study results conducted by Robert (2000), Mervat Samir Hussein (2003), Sally Mohamed Abdul Latif (2005), Hamid Mohamed El Komy (2007), Hassan Ibrahim (2010), Hani Ahmed Abdel Aal (2011), Dina Abdel Rahim Mehana (2014), Azza Ahmed Al-Said (2014), Hisham Azab Abdul Aziz 
(2014), on the effectiveness of the use of electronically Personalized System of Instruction (Keller Plan) to learn and master motor skills in individual and team sports. [39, $25,12,7,8,29,11,15,30]$

In this regard, Ibrahim Abdul Wakil (1998), AlGhareeb Zahir and Iqbal Behbehani (1999) indicated that the use of computer as a sophisticated technology is an integrated introduction and approach to teach a variety of subjects and curricula. This causes a substantial improvement in the students' achievement. It also causes positive change in their attitudes towards those curricula, and reduced the time necessary for teaching and learning either at the level of individuals or groups. [1, 4]

Thus, the first hypothesis is realized.

\section{B. Second Hypothesis Results Discussion:}

The results of table (5) indicated that there are statistically significant differences at the level of 0.05 between pre- and post-tests of the control group (low level) in the performance level of overhand passing skill in volleyball in favor of the posttest.

The results of table (8) also indicated that there are statistically significant differences at the level of 0.05 between pre- and post-tests of the control group (high level) in the performance level of overhand passing skill in volleyball in favor of the posttest.

The researcher attributed the improvement of the members of the control group (low-level, high level) in the performance level of overhand passing skill in volleyball to the interest of female teacher to practically display the skill under discussion, and to provide verbal simplified explanation for the skill to be learned so that the female learners can form a clear vision about the required skill performance. The Female teacher also provides guidance and advice whenever necessary so that female learner can fix technical errors as they arise.

This is in line with what indicated by the Martin \& Lumsden (1987) that when a teacher gives the learner a clear idea of proper scientific performance, learner's performance becomes more 
effective. [35] Thus, one of the best methods when learning the skills is that the teacher displays the skill and performs a correct model to the learner to discover his body movements.

Thus, the second hypothesis is realized.

\section{Third Hypothesis Results Discussion:}

Noting the results of table (6), it indicates that there are statistically significant differences at the level of 0.05 between post-tests of experimental and control groups (low level) in the performance level of overhand passing skill in volleyball in favor of the experimental group.

The results of table (9) indicate that there are statistically significant differences at the level of 0.05 between post-tests of experimental and control groups (high level) in the performance level of overhand passing skill in volleyball in favor of the experimental group.

The researcher attributed the excellence of the experimental group members over the control group members in the performance level of overhand passing skill in volleyball to provide the skill with a variety of logical sequential clarification in the programmed educational system, which was presented to the members of the experimental group. This contributed to increasing the level of their skill achievement, and made the female learners in an ongoing response during the learning process and made the lesson be more interesting. This also arose meaningful, vital, self-activity from the female learners. We do not find this in the instruction approach. This is consistent with what indicated by Hussein Kamel Bahaa El-ddin (2002) that the differences and uniqueness among the learners must be taken into account. [9] The beginning of that is the division of learners into average, those with special conditions, and genius. This is important to deal with the uniqueness and differences among learners.

Abdul Hafiz Mohamed Salama (2012) added that the educational techniques used for collective self-learning, learning according to the needs, methods directed at a specific program, and self- 
administration means succeeded in helping learners to acquire cognitive and motor skills. [13]

Thus, the third hypothesis is realized.

\section{Findings:}

In the light of the research objectives and hypotheses, the research sample limits and results, the researcher could conclude the following findings:

\section{Electronically}

Personalized System of Instruction by using hypermedia positively affects the performance level of overhand passing skill in volleyball among the members of experimental group (low level, high level).

2. The instruction approach positively affects the performance level of overhand passing skill in volleyball among the members of the control group (low level, high level).

3. The effectiveness of electronically Personalized System of Instruction using hypermedia is greater than the instruction approach in the performance level of overhand passing skill in volleyball.

Recommendations:
In light of the research results, the researcher recommends the following:

1. Personalized System of Instruction (Keller Plan) by using hypermedia should be used in learning and mastering skill of overhand passing in volleyball for female students of Faculty of Physical Education in Port Said.

2. Initial evaluation of female students should be conducted from the beginning to categorize them into homogeneous groups.

3. Training courses should be held for the faculty members and their assistants on the use of modern technological techniques in teaching various aspects of volleyball curriculum of in order to avoid the stagnation of the traditional method of teaching.

4. Similar studies should be conducted, using the other personalized instruction strategies identifying its impact on learning the rest of different aspects of volleyball curriculum for the female students of Faculty of Physical Education in Port Said.

References

I. Arabic References: 
1. Ibrahim Abdul Wakil El-Far (1998): The Educations of Computer and the Challenges of Twentieth Century Aspiration, Dar El-fikr el-Arabi, Cairo.

2. Abul-Naga Ahmad Izz al-Din (2000): The Recent Trends in teaching methods of Physical Education, Dar alAlasdekaa, Mansoura

3. Al-Sayed Mohamed Khairy (1989): Higher IQ Test (instructions and applications), Dar al-Nahda al-Arabyea, Cairo.

4. Al-Ghareeb Zahir, Iqbal Behbehani (1999): Education Technology, Future View, 2nd edition, Dar alKitab Al-hadis, Cairo.

5. Ellen Wadih Farag (1990): Volleyball, the Guide of Teacher and Coach and Player, Monchaa Al-Maaref, Alexandria.

6. Tawfik Marai, Mohamed Al-Hela (2012): Personalized System of Instruction, Dar Al Fiker Publishers \& Distributors, Amman, Jordan.

7. Hamid Mohamed El Komy (2007): "The impact of Keller Plan to Personalize Instruction by Hypermedia on the Performance Level of Shooting and Cognitive
Achievement in Handball," Journal of Sports Science and Arts, Vol. 28, Faculty of Physical Education for Girls, Helwan University.

8. Hassan Ibrahim Ali (2010): "Enhanced Electronically Personalized System of Instruction by Using Systemic Modules and Their Impact on the Outcomes of Learning Some Skill and Cognitive Aspects in Football," Journal of Sports Science and Arts, Vol. 35, Faculty of Physical Education for Girls, Helwan University.

\section{Hussein Kamel Bahaa}

Eddin (2002): The Education and Future, Dar el-Marf, Cairo.

10. Helmy El-Wakil, Hussein Bashir (2005): the Recent Trends in Planning and Developing a program for the first phase, Dar El Fikr El Arabi, Cairo.

11. Dina Abdel Rahim Mehana (2014): "The Impact of an Educational Program of Keller Plan on the Performance Level of Basic Skills in Table Tennis for the Female Students of Faculty of Physical Education, Asyut University," Master Thesis, Faculty of Physical Education, Asyut University 
12. Sally Mohamed Abdel Latif (2005):

"The

Effectiveness of a Proposed Educational Program with Keller Plan (Personalized System of Instruction) by Using Hypermedia to learn some Hockey Skills for Female Students of Faculty of Physical Education, Tanta University," $\mathrm{PhD}$ thesis, Faculty of Physical Education, Tanta University.

\section{Abdul Hafiz Mohamed} Salama (2012): An Introduction to the Technology of Education, 2nd edition, Dar Al Fikr Publication \& Distribution, Cairo.

14. Abdul Hamid Sharaf (2001): The Technology of Education in Physical Education, Markaz Al-ketab for Publishing, Cairo.

15. Azza Ahmed Said (2014): "The Impact of an Educational Program with Keller Plan (Personalized System of Instruction) by Using Hypermedia to Learn Some Basic Skills in Volleyball for Hearing Impaired People," Journal of Sports Science and Arts, Vol. (34), 2nd edition, Faculty of Physical Education for Girls, Helwan University.

16. Ali Hassanein Hassab Allah et al. (1999): The
Scientific Basis for Teaching Volleyball, Markaz Al-ketab for Publishing, Cairo.

17. Ali Mohammed AbdelMoneim (2005): Education Technology and Teaching Aids, Dar Al-Maarefa AlGameia, Alexandria.

18. Ali Mustafa Taha (1999): Volleyball, Dar El Fikr El Arabi, Cairo.

19. Kamal

Yusuf

Iskandar, Ahmed Kamel AlHoussary, Sophie Zaki (2000): Education Technology and Educational Multimedia, Nour Computer and Printing, Alexandria.

20. Mohamed Hassan Allawi, Mohamed Nasreddin Radwan (2001): Motor Performance Tests, 5th edition, Dar El Fikr El Arabi, Cairo.

21. Mohammad Reda alBaghdadi (1998): The Technology of Education and Learning, Dar El-fikr el-Arabi, Cairo.

22. Mohamed

Sobhi

Hassanein (2001):

Measurement and Evaluation in Physical Education and Sports, Part 1, 4th edition, Dar El-fikr el-Arabi, Cairo.

23. Mohamed Sobhi Hassanein, Hamdi Abdel Moneim Ahmed (1997): The Scientific Bases of Volleyball 
"Physical, Skill, Cognitive, Psychological, Analytical," Markaz Al-ketab, Cairo. 24. Mohamed Attia Khamis (2003): Educational Technology Products, Dar alKalima Library, Cairo.

25. Mervat Samir Hussein (2003): "The Effectiveness of a Proposed Educational Program with Keller Plan (Personalized System of Instruction) By Using Multimedia to learn some Volleyball skills for Female Students of Faculty of Physical Education in Minia," $\mathrm{PhD}$ thesis, Faculty of Physical Education, Minia University.

26. Mustafa Abdel Samie Mohamed (1999): Education Technology, Arab Studies, Markaz Al-ketab for Publishing, Cairo.

27. Mohamed Saad Zaghloul, Makarim Abu Hrjh, Hani Said Abdel Moneim (2001): The Technology of Education and Its Methods of Physical Education, Markaz Al-ketab for Publishing, Cairo.

28. Mahdi Salem (2002): The Techniques and Means of Education, Dar El-fikr elArabi, Cairo.

29. Hani Ahmed Abdel Aal (2011): "The Effectiveness of Personalized System of
Instruction $\quad \mathrm{Bu} \quad$ Using Hypermedia on the Performance level of Basketball Skills for Deaf and Dumb Pupils," Journal of Sports Science and Arts, Vol. (38), Faculty of Physical Education for Girls, Helwan University.

30. Hisham Azab Abdul Aziz (2014): "The Impact of Enhanced Electronically Personalized System of Instruction on the Aspects of Learning Serve Skill in Volleyball Among the Students of Faculty of Physical Education," Journal of Sports Education Research, Vol. (50), Edition (96), Part I, Faculty of Physical Education for Boys, Zagazig University.

31. Wafika Mustafa Salem (2001): The Technology of Education and Learning in Physical Education, Part I, Monshat Al-Maaref, Alexandria.

\section{Foreign References:}

32. Emck, J., \& Ferguson, H., (2005): A computerManged Kelle Plan (Electricity and Magnetum) Iop Electronic, Journal Plyicosics Education, Tech Univ., of Einrdhoven, Netherland, Http://www.iop olg/fy/abstract/10031. 
33. Gold, R., (1998):

Microcomputer applications in health education, Dubuque, IA William C. Brown publishers. 34. Kevien Oliver (2000): Personalized System of Instruction, www.keo.com. 35. Martin \& Lumsden (1987): Coaching an Effective Behavioral Approach, college publishing, Toronto.

36. Mclaughin, T.,(1999): Use of A Personalize System of Instruction Without A sameday Retake Contingency on Spelling Performance of Behaviorally of Disordered Children., Behavioral Disorders, No.,25.

37. Michelle, A., (2010): Integrating Hypermedia to Class Room Instruction Developing Anon-Linear Teaching Style, Grand Center for Publications and Administration‘Saint-Germain,
California State University Long Beach.

38. Najar (2005):

Lawrence Information and Learning, Journal of Educational Multimedia and Hypermedia, Http://

multimedia_and_learning html.

39. Robert, A., (2000): A written Program of SelfInstruction For Learning The Cartwheel in Gymnastics M.S Physical Education, Completed Research Health, Physical Education and Recreation, Vol., 39.No.,2.

40. Zencius, A., (2002): A Personalize System of Instruction for Teaching Checking Account Skills to Adults With Mild Disabilities , Journal of Applied Behavior Analysis. 